\title{
Assessment of learners' exposure to health education and promotion at school in the Limpopo Province of South Africa
}

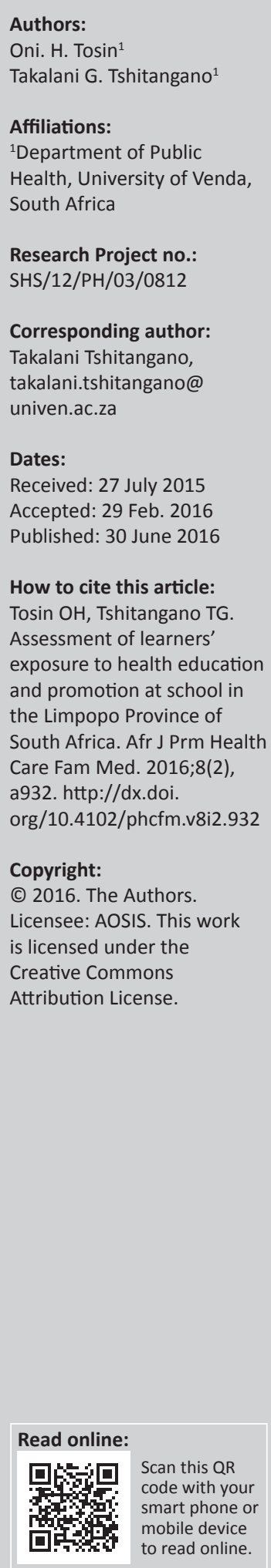

Background: School participation and educational attainment among adolescents have been rising rapidly in the developing world. Thus, to attain Millennium Development Goal 6 (Combat HIV and/or AIDs, malaria and other diseases), it is crucial to seize the opportunity to educate and encourage teenagers about healthy choices and proper social behaviours that will continue into adulthood.

Aim: This study aimed to assess the exposure of rural secondary school learners to health education and promotion at schools in the Limpopo Province of South Africa.

Setting: This study was carried out at 10 secondary schools in Vhumbedzi educational circuit.

Methodology: The study adopted a cross-sectional quantitative approach. Data were collected from 338 randomly selected learners from 10 secondary schools that make up a rural Vhumbedzi circuit in the Limpopo province. A self-administered questionnaire was used to collect data.

Results: The findings showed that, $102(66.07 \%)$ male and $121(67.60 \%)$ female learners reported that they were taught about physical changes that occur during adolescence. In the same vein, most of the participants $(n=128,84.39 \%)$ and $(n=152,85.39 \%)$ males and females respectively claimed to have been taught about sexually transmitted diseases.

Conclusion: In this study the secondary schools in the Limpopo Province of South Africa are making efforts to uphold and expose their learners to health education and promotion at school.

\section{Introduction}

Since the 1950s, schools have been a focal setting for health promotion and health education with the aim of teaching young people about health and its determinants, so as to empower them to develop the skills to resist unhealthy lifestyles. ${ }^{1}$ During the 1990s, the World Health Organization, working jointly with the various organisations in each country, developed the health promoting schools initiatives, which involve a multi-factorial approach that covers teaching health knowledge and skills in the classroom, in order to change social and physical environment of the school, promote healthy development of school-going children and the communities in which they live and learn. ${ }^{1}$ The school health promotion initiatives were developed based on a medical model that seeks to prevent certain diseases or health problems and to address all the major public health problems that most adolescents are battling with in the 21st centuries, namely; drug and alcohol abuse, smoking, unhealthy eating, lack of physical activity, obesity, unwanted pregnancy, sexual transmitted infections and human immunodeficiency virus/acquired immunodeficiency syndrome (HIV and/or AIDS) as well as injuries among the adolescent population..$^{2,3,4,5}$

Promoting the health and safety of adolescents as well as combating HIV and/or AIDs, malaria and other diseases - Millennium Development Goal (MDG) 6 - is of great importance for the future well-being of all nations. Adolescence represents a special period in the life cycle whereby an individual is no longer a child and not yet an adult. During this phase of life, young people tend to develop attitudes and most engage in health practices that affect their present safety and well-being, which may also influence their future either positively or negatively. ${ }^{6,7,8}$ Because school participation and educational attainment among adolescents have been rising rapidly in the developing world, it is therefore crucial to educate teenagers about healthy choices and proper social behaviours that will continue into their adulthood. In addition, efficacious transition of 
adolescents to adulthood, whether they are transitioning to marriage and parenthood, to household management, work, or to law abiding citizens, basically depends on the combination of good education and good health. ${ }^{9}$

However, educating and promoting adolescent well-being cannot be achieved by only one sector of the society. It takes the collective efforts of a broad range of societal sectors and institutions including; parents and families, health care providers, schools and tertiary institutions, community organisations and agencies that serve youth, faith-based organisations and adolescents themselves. Together, these bodies have a role to play in ensuring a nurturing structure and environment, as well as opportunities for growth that support and sustain the healthy development of young people. ${ }^{12,13,14}$

The question that comes to mind is 'why should a country care about school health education and promotion?' A country should care because the adolescents today are the leaders tomorrow. Thus, the health and well-being of our nation's adolescents and youth are not matters of luck, chance, or random event. It must be a planned, well-designed, well-resourced, sustained, monitored, and evaluated program that should be incorporated into the nation's schools. Moreover, a study of this nature is uncommon in South Africa. Whereas, if South Africa wants to achieve MDG 6, which aims to combat HIV and/or AIDs, malaria, and other diseases, a study of this nature cannot be undermined in this era. It is against this background that this study was undertaken.

\section{Purpose of the study}

The aim of this article is to assess the learners' exposure to health education and promotion at schools in the Limpopo Province of South Africa.

\section{Methodology Study design}

Based on the purpose of the study, a quantitative crosssectional descriptive survey design was adopted and this design is deemed suitable by the researchers because it describes and interprets phenomena that are in existence. ${ }^{15}$

\section{The study setting}

The study was conducted at Vhumbedzi educational circuit situated in the east of Sibasa in the Vhembe District and north of Kruger National Park. Vhumbedzi circuit and secondary school learners were the phase one population of the study.

\section{Population and sample}

The target population for this study was 10 secondary schools in the Vhumbedzi educational circuit with a total population of 5019 learners involved in the study.

\section{Sample selection and procedure}

Based on the sampling frame of 5019, sample size of $n=370$ was calculated using Slovin's formula. A two-stage stratified sample selection process was used using grades and gender as strata within each of the 10 participating schools. Learners were selected randomly within each stratum based on population, which ensured proportional representativeness of grade and gender in the final sample (Table 1).

\section{Data collection instrument}

A self-administered questionnaire, adapted from the 2011 high school Youth Risk Behaviour Survey (YRBS) of the Centres for Disease Control and Prevention ${ }^{16}$ was used as an instrument in this study. The questionnaire was in English and required approximately 50-60 min to complete. Caution was taken to ensure that it was user-friendly and understandable.

\section{Instrument validity and reliability}

To ensure validity and reliability, the instrument was adapted from the YRBS questionnaire of the Centres for Disease Control and Prevention ${ }^{16}$ to suit the local conditions. A wide range of literature was also consulted on the variables of interest. Also, the instrument was pre-tested on some volunteer learners in a school similar to the target population. Pre-testing results were used to rephrase and modify some aspects of the questionnaire thus making it suitable and comprehensible to the participants.

\section{Data collection process}

The study was conducted over a 3-week period between October and November 2012. All 10 schools were visited by the research team to identify the learners who were to participate in the study. Dates for data collection were prearranged by circuit office and school authorities; and within each participating school, a special class was organised where the research team briefed the participants and assisted in facilitating the administration of the instrument and addressing issues arising thereof. The administration of the questionnaires lasted approximately 60 minutes.

\section{Data analysis}

The Statistical Package for the Social Sciences (SPSS) version 21.0 software was used to analyse the data. Descriptive statistics were also used to summarise the data.

\section{Ethical considerations}

An ethical clearance certificate (SHS/12/PH/03/0812) was obtained from the Research and Innovation Directorate of the University of Venda for the study. Further permissions were also acquired from the Department of Health - Limpopo Province, the Vhumbedzi circuit office, and each school administration. In addition, the participants and their 
TABLE 1: Two-stage stratified sample selection process.

\begin{tabular}{|c|c|c|c|c|c|c|c|c|c|c|c|c|c|}
\hline \multirow[t]{2}{*}{ Name of school } & \multirow[t]{2}{*}{ Gender } & \multicolumn{5}{|c|}{ Total population per grade and gender } & \multirow[t]{2}{*}{ Total } & \multicolumn{5}{|c|}{ Proportional sample size per grade and gender } & \multirow[t]{2}{*}{ Total } \\
\hline & & Gr 8 & Gr 9 & Gr 10 & Gr 11 & Gr 12 & & Gr 8 & Gr 9 & Gr 10 & Gr 11 & Gr 12 & \\
\hline \multirow[t]{3}{*}{ Tondalushaka } & $\mathrm{M}$ & 94 & 36 & 83 & 54 & 63 & 330 & 7 & 2.7 & 6.1 & 4 & 4.6 & $24.3 / 25$ \\
\hline & $\mathrm{F}$ & 78 & 56 & 75 & 44 & 60 & 313 & 5.8 & 4.1 & 5.5 & 3.2 & 4.4 & $23.1 / 23$ \\
\hline & Total & 172 & 92 & 158 & 98 & 123 & 643 & 12.8 & 6.8 & 11.6 & 7.2 & 9.0 & 47.4 \\
\hline \multirow[t]{3}{*}{ Ntsedzeni } & $M$ & 34 & 57 & 81 & 63 & 19 & 254 & 2.5 & 4.2 & 6 & 4.6 & 1.4 & $18.7 / 19$ \\
\hline & $\mathrm{F}$ & 38 & 49 & 63 & 79 & 44 & 273 & 2.8 & 3.6 & 4.6 & 5.8 & 3.2 & $20.0 / 21$ \\
\hline & Total & 72 & 106 & 144 & 142 & 63 & 527 & 5.3 & 7.8 & 10.6 & 10.4 & 4.6 & 38.7 \\
\hline \multirow[t]{3}{*}{ Vuvumutshena } & $M$ & 47 & 29 & 30 & 23 & 18 & 147 & 3.5 & 2.2 & 2.2 & 1.7 & 1.3 & $10.9 / 11$ \\
\hline & $\mathrm{F}$ & 54 & 25 & 43 & 37 & 11 & 170 & 4 & 1.8 & 3.2 & 2.7 & 0.8 & $12.5 / 13$ \\
\hline & Total & 101 & 54 & 73 & 60 & 29 & 317 & 7.5 & 4.0 & 5.4 & 4.4 & 2.1 & 23.4 \\
\hline \multirow[t]{3}{*}{ George Ntodeni } & $M$ & 43 & 42 & 63 & 49 & 20 & 217 & 3.2 & 3.1 & 4.6 & 3.6 & 1.5 & $16 / 17$ \\
\hline & $\mathrm{F}$ & 47 & 36 & 61 & 46 & 15 & 205 & 3.5 & 2.7 & 4.5 & 3.4 & 1.1 & $15.2 / 16$ \\
\hline & Total & 90 & 78 & 124 & 95 & 35 & 422 & 6.7 & 5.8 & 9.1 & 7.0 & 2.6 & 31.2 \\
\hline \multirow[t]{2}{*}{ Mpandeli } & M & 107 & 101 & 93 & 68 & 60 & 429 & 7.9 & 7.4 & 6.9 & 5 & 4.4 & $31.6 / 31$ \\
\hline & Total & 231 & 221 & 202 & 150 & 112 & 916 & 17 & 16.2 & 14.9 & 11 & 8.2 & 67.3 \\
\hline \multirow[t]{3}{*}{ Ranndogwana } & M & 65 & 45 & 88 & 52 & 26 & 276 & 4.8 & 3.3 & 6.5 & 3.8 & 1.9 & $20.3 / 21$ \\
\hline & $\mathrm{F}$ & 55 & 67 & 75 & 52 & 14 & 263 & 4.1 & 4.9 & 5.5 & 3.8 & 1.0 & $19.3 / 20$ \\
\hline & Total & 120 & 112 & 163 & 104 & 40 & 539 & 8.9 & 8.2 & 12 & 7.6 & 2.9 & 39.6 \\
\hline \multirow[t]{3}{*}{ Funzwani } & M & 53 & 62 & 42 & 39 & 7 & 203 & 3.9 & 4.6 & 3.1 & 2.9 & 0.5 & $15 / 16$ \\
\hline & $\mathrm{F}$ & 43 & 53 & 48 & 25 & 8 & 177 & 3.2 & 3.9 & 3.5 & 1.8 & 0.6 & $13 / 14$ \\
\hline & Total & 96 & 115 & 90 & 64 & 15 & 380 & 7.1 & 8.5 & 6.6 & 4.7 & 1.1 & 28 \\
\hline \multirow[t]{3}{*}{ Ntevhedzeni } & M & 15 & 14 & 30 & 11 & 13 & 83 & 1.1 & 1 & 2.2 & 0.8 & 1 & $6.1 / 6$ \\
\hline & $\mathrm{F}$ & 11 & 4 & 30 & 22 & 10 & 77 & 0.8 & 0.3 & 2.2 & 1.6 & 0.7 & $5.6 / 7$ \\
\hline & Total & 26 & 18 & 60 & 33 & 23 & 160 & 1.9 & 1.3 & 4.4 & 2.4 & 1.7 & 11.7 \\
\hline \multirow[t]{3}{*}{ Limbedzi } & M & 26 & 22 & 26 & 23 & 22 & 119 & 1.9 & 1.6 & 1.9 & 1.7 & 1.6 & $8.7 / 10$ \\
\hline & $\mathrm{F}$ & 26 & 18 & 42 & 24 & 11 & 121 & 1.9 & 1.3 & 3.1 & 1.8 & 0.8 & $8.9 / 9$ \\
\hline & Total & 52 & 40 & 68 & 47 & 33 & 240 & 3.8 & 2.9 & 5.0 & 3.5 & 2.4 & 17.6 \\
\hline Milton Mpfumedzeni & M & 110 & 86 & 120 & 73 & 56 & 445 & 8.1 & 6.3 & 8.8 & 5.4 & 4.1 & $32.7 / 32$ \\
\hline Grand Total $(N)$ & & & & & & & 5019 & & & I Sampl & & & $\approx 370$ \\
\hline
\end{tabular}

Source: Project data analysis, 2012

TABLE 2: Summary of the demographic profile of the respondents.

\begin{tabular}{lcc}
\hline Gender & Frequency & $\mathbf{\%}$ \\
\hline Males & 151 & 45.6 \\
Females & 180 & 54.4 \\
\hline
\end{tabular}

Source: Project data analysis, 2012

parents signed an informed consent assuring anonymity, confidentiality, and voluntary participation before the administration of the questionnaire.

\section{Results}

\section{Demographic profile of the participants}

Though self-administered questionnaires were distributed to 370 learners proportionally according to grades, added together the response rate was $89 \%(n=331)$. Thus, about 151 $(45.6 \%)$ of the respondents were males whereas $54.4 \%$ $(n=180)$ of the respondents were females (Tables 2 and 3).

\section{Health education and promotion at school}

Of the respondents, $102(66.07 \%)$ male and 121 (67.60\%) female learners reported that they were taught physical changes that occur during adolescence (Table 1). In the same vein, most of the participants $128(84.39 \%)$ and $152(85.39 \%)$ male and female respectively claimed to have been taught about sexually transmitted diseases. Similarly, the majority of the learners 139 (92.05\%) male and 162 (90.50\%) female were taught about alcohol and drug abuse. Meanwhile, 144 $(94.74 \%)$, and $169(94.95 \%)$ male and female respondents were taught about HIV and/or AIDS. In addition, 115 $(76.16 \%)$ males and $115(63.89 \%)$ females attested to have being taught about the danger of physical fights and violence.

\section{Discussion}

The findings of this study revealed that most of the learners had been taught various topics related to health education and promotion with $102(66.07 \%)$ male and 121 (67.60\%) female learners reporting being taught physical changes that occur during adolescence. In line with this, most of the respondents $(n=128,84.39 \%)$ and $(n=152,85.39 \%)$ male and female respectively claimed to have been taught about sexually transmitted diseases. Similarly, the majority of the learners $(n=139,92.05 \%)$ male and $(n=162,90.50 \%)$ female were taught about alcohol and drug abuse. Meanwhile, 144 (94.74\%), 169 (94.95\%) male and female respondents were taught about HIV / and/or AIDS. Also, 115 (76.16\%) males and 115 (63.89\%) females attested to have been taught about the danger of physical fights and violence. It is not surprising that learners were exposed to these topics, because the South Africa 
TABLE 3: Summary of the frequency and percentages of learners; exposure to health education at schools.

\begin{tabular}{|c|c|c|c|c|c|c|c|c|c|c|c|c|}
\hline \multirow{3}{*}{$\begin{array}{l}\text { Health education \& } \\
\text { Promotion }\end{array}$} & \multicolumn{6}{|c|}{ Male } & \multicolumn{6}{|c|}{ Female } \\
\hline & \multicolumn{2}{|c|}{ Yes } & \multicolumn{2}{|c|}{ No } & \multicolumn{2}{|c|}{ Unsure } & \multicolumn{2}{|c|}{ Yes } & \multicolumn{2}{|r|}{ No } & \multicolumn{2}{|c|}{ Unsure } \\
\hline & Number & Percentage & Number & Percentage & Number & Percentage & Number & Percentage & Number & Percentage & Number & Percentage \\
\hline $\begin{array}{l}\text { Physical changes } \\
\text { that occur during } \\
\text { adolescent }\end{array}$ & 102 & 66.07 & 38 & 24.84 & 13 & 8.49 & 121 & 67.60 & 41 & 22.90 & 17 & 9.50 \\
\hline Menstruation & 83 & 58.04 & 40 & 27.97 & 20 & 13.99 & 137 & 77.40 & 33 & 18.65 & 7 & 3.95 \\
\hline Wet dreams & 98 & 64.05 & 43 & 28.10 & 12 & 7.85 & 87 & 51.48 & 54 & 31.95 & 28 & 16.57 \\
\hline Sexual harassment & 113 & 74.83 & 31 & 20.53 & 7 & 4.64 & 127 & 70.56 & 38 & 21.11 & 15 & 8.33 \\
\hline $\begin{array}{l}\text { How pregnancy } \\
\text { occurs }\end{array}$ & 121 & 80.13 & 23 & 15.23 & 7 & 4.64 & 146 & 81.11 & 20 & 11.11 & 14 & 7.78 \\
\hline Contraception & 96 & 63.16 & 50 & 32.89 & 7 & 4.61 & 114 & 64.05 & 51 & 28.65 & 13 & 7.30 \\
\hline HIV/AIDS & 144 & 94.74 & 5 & 3.29 & 3 & 1.97 & 169 & 94.95 & 7 & 3.93 & 2 & 1.12 \\
\hline $\begin{array}{l}\text { Sexually Transmitted } \\
\text { Infections }\end{array}$ & 128 & 84.77 & 17 & 11.26 & 6 & 3.97 & 152 & 85.39 & 19 & 10.67 & 7 & 3.93 \\
\hline Nutrition & 123 & 80.39 & 22 & 14.38 & 8 & 5.23 & 135 & 76.28 & 29 & 16.38 & 13 & 7.34 \\
\hline $\begin{array}{l}\text { Where to get } \\
\text { reproductive health } \\
\text { services }\end{array}$ & 92 & 60.93 & 44 & 29.14 & 15 & 9.93 & 103 & 57.54 & 46 & 25.70 & 30 & 16.76 \\
\hline TB & 132 & 88.59 & 11 & 7.38 & 6 & 4.03 & 157 & 88.70 & 16 & 9.04 & 4 & 2.26 \\
\hline $\begin{array}{l}\text { Personal hygiene } \\
\text { and cleanliness }\end{array}$ & 117 & 76.47 & 24 & 15.69 & 12 & 7.84 & 125 & 70.63 & 31 & 17.51 & 21 & 11.86 \\
\hline $\begin{array}{l}\text { School environment } \\
\text { hygiene and } \\
\text { cleanliness }\end{array}$ & 119 & 79.87 & 21 & 14.09 & 9 & 6.04 & 136 & 76.84 & 23 & 12.99 & 18 & 10.17 \\
\hline $\begin{array}{l}\text { Chronic illnesses } \\
\text { such as cancer, } \\
\text { diabetes etc }\end{array}$ & 124 & 81.58 & 22 & 14.47 & 6 & 3.95 & 141 & 79.21 & 25 & 14.05 & 12 & 6.74 \\
\hline Risk behaviours & 121 & 79.61 & 25 & 16.45 & 6 & 3.94 & 153 & 85.00 & 22 & 12.22 & 5 & 2.78 \\
\hline $\begin{array}{l}\text { Alcohol and drug } \\
\text { abuse }\end{array}$ & 139 & 92.05 & 8 & 5.30 & 4 & 2.65 & 162 & 90.50 & 16 & 8.94 & 1 & 0.56 \\
\hline Smoking & 133 & 88.08 & 14 & 9.27 & 4 & 2.65 & 163 & 91.06 & 14 & 7.82 & 2 & 1.12 \\
\hline $\begin{array}{l}\text { Your rights as } \\
\text { adolescents }\end{array}$ & 123 & 80.00 & 23 & 15.33 & 4 & 2.67 & 151 & 84.36 & 19 & 10.61 & 9 & 5.03 \\
\hline $\begin{array}{l}\text { Importance of } \\
\text { exercise }\end{array}$ & 132 & 88.59 & 14 & 9.40 & 3 & 2.01 & 154 & 87.01 & 17 & 9.60 & 6 & 3.39 \\
\hline Dangers of obesity & 116 & 77.85 & 22 & 14.77 & 11 & 7.38 & 129 & 71.67 & 38 & 21.11 & 13 & 7.22 \\
\hline $\begin{array}{l}\text { Choice of } \\
\text { termination of } \\
\text { pregnancy }\end{array}$ & 88 & 58.67 & 51 & 34.00 & 11 & 7.33 & 97 & 53.89 & 62 & 34.44 & 21 & 11.67 \\
\hline $\begin{array}{l}\text { Danger of physical } \\
\text { fights and violence }\end{array}$ & 115 & 76.16 & 28 & 18.54 & 8 & 5.30 & 115 & 63.89 & 48 & 26.67 & 17 & 9.44 \\
\hline
\end{tabular}

Source: Project data analysis, 2012

Responses above are based on whether learners have been taught the above during 2012.

government has sworn to 'Put Children First' giving their needs the highest priority. ${ }^{3,510}$ In order to uphold the rights of children and adolescents and make provision for them to attain their full potential in all facets of their lives, the Health, Education, and Social Development sectors were entrusted with a vital role in developing the National School Health Policy and Implementation Guidelines. This policy was developed and communicated to all schools. ${ }^{5,11}$ According to the policy, it was mandatory for all high schools to incorporate important health factors impacting on the development of children and youth of school-going age including issues relating to sexuality, HIV and/or AIDS and reproductive health, trauma and violence, substance abuse, and mental health problems. Such factors should be addressed through health promotion and health education activities and need to be incorporated into the life orientation area of the curriculum. ${ }^{5,13}$

Furthermore, 123 (80.39\%) male and 135 (76.28\%) female learners declared that they had been taught about nutrition. Of the respondents, $133(88.08 \%)$ male and $163(91.06 \%)$ female learners affirmed that they knew about the dangers associated with smoking. Because most of the respondents had learnt about risks associated with improper nutrition and smoking etc cetera; it is most likely that they will abstain from such acts, hence specific diseases and public health problems accompanying drug and alcohol abuse, smoking, unhealthy eating et cetera, can be minimised in the society. ${ }^{3}$ However, some students were unsure of whether or not they had been taught about particular issues; suggesting that they may have been taught about the subjects but could not recall this.

\section{Recommendations}

In this study, a minor proportion of the participants claimed that they were not taught some of the topics; therefore it is very important to ensure that no student or learner is left out when it comes to exposure to health education and promotion, because knowledge is power and all the learners need to be empowered to make informed decisions. Also, more studies are needed in this area especially in other educational circuits of Limpopo Province. 


\section{Limitations of the study}

The fact that this study was conducted in one educational circuit limits the generalisation of the study findings to this circuit only.

\section{Conclusion}

This study shows that secondary/high schools in the Limpopo Province of South Africa are making efforts to uphold and expose their learners to health education and promotion at school.

\section{Acknowledgements}

The authors will like to appreciate the different authorities that gave permission to conduct this study. We also extend our appreciations to all the respondents in this study.

\section{Competing interests}

The authors declare that they have no financial or personal relationships which may have inappropriately influenced them in writing this article.

\section{Authors' contributions}

O.H.T. and T.G.T. equally contributed to the research and writing of this article.

\section{References}

1. Madsen KD, Simovska V. Mapping of policies shaping the agenda within health. In: Research in schools for health and sustainability. Department of Education, Aarhus University, 2012; p. 507-520.

2. Samdal O, Rowling L. Implementation strategies to promote and sustain health and learning in school. Schools for health and sustainability. The Netherlands: Springer; 2015; p. 233-252.
3. Kwatubana S, Kheswa J. Integrated approach to health promotion: The South African schools' role. Mediterr J Soc Sci. 2014;5(20):1713.

4. Cheng NYI, Wong MYE. Knowledge and attitude of school teachers towards promoting healthy lifestyle to students. Health. 2015;7(1):119-126. http://dx.doi. org/10.4236/health.2015.71014

5. South Africa. Integrated school health policy. Pretoria: Government Printer [documented on the Internet]. c2012 [cited 2015 Apr 28] Available from: http:// www.education.gov.za/LinkClick.aspx?fileticket=pj7clv8qGMc\%3D\&tabid=390\& $\mathrm{mid}=1125$

6. Cardoza VJ, Docum PI, Fryer SG, Gold MA, Butler J. Sexual health behavior interventions for U.S. Latino adolescents: A systematic review of the literature. J Pediatr Adolesc Gynecol. 2011;25:136-149. doi:10.1016/j.jpag.2011.09.011

7. Park S, Lee EY, Gittelsohn J, Nkala D, Choi BY. Understanding school health environment through interviews with key stakeholders in Lao PDR, Mongolia, Nepal and Sri Lanka. Health Educ Res. 2015;30(2):285-297. http://dx.doi. org/10.1093/her/cyu069

8. Balcou-Debussche M, Rogers C. Promoting health education in a context of strong social and cultural Heterogeneity: The case of reunion Island. Schools for Health and Sustainability. The Netherlands: Springer; 2015; p. 291-312.

9. Jones AJ, Mathews C, Flisher JA. Can peer education make a difference? Evaluation of a South African adolescent peer education program to promote sexual and reproductive health. AIDS Behav. 2011;15(8):1605-1611. http://dx.doi. org/10.1007/s10461-011-0012-1

10. WHO. Facts sheet why is giving special attention to adolescents important for achieving Millennium Development Goal 5 [documented on the Internet]. c2011 [cited 2015 Apr 28]. Available from: http://www.who.int/making_pregnancy safer/events/2008/mdg5/adolescent_preg.pdf

11. Shung-King M. From 'stepchild of primary healthcare' to priority programme: Lessons for the implementation of the National Integrated School Health Policy in South Africa. S Afr Med J. 2013;103(12):895-898. http://dx.doi.org/10.7196/ SAMJ.7550.

12. Sznitman S, Vanable PA, Carey $P$, et al. Using culturally sensitive media messages to reduce HIV-associated sexual behaviour in high-risk African American adolescents: Results from a randomized trial. J Adolesc Health. 2011;49:244-251.

13. Kalembo FW, Zgambo M, Yukai D. Effective adolescent sexual and reproductive health education programs in sub-Saharan Africa. Calif J Health Promot. 2013;11:33-42.

14. Madsen KD, Nordin LL, Simovska V. Linking health education and sustainability education in schools: Local transformations of international policy. schools for health and sustainability. The Netherlands: Springer; 2015; p. 81-109.

15. Brink H, Van Der Walt C, Van Rensburg G. Fundamentals of research methodology for health care professional. 2nd ed. Cape Town: Juta; 2006.

16. Centre for Disease Control (CDC). Youth risk behaviour survey questionnaire [document on the Internet]. c2011 [cited 2015 May 1]. Available from: http:// www.cdc.gov/healthyyouth/yrbs/questionnaire_rationale.htm 